\title{
Counter Measure and Trend Analysis of Vehicle Tail Gas Pollution in Hangzhou \\ Ya-Jie SHEN*
}

Department of traffic management engineering, Zhejiang Police college, Hangzhou 310053, China shen_yajie@163.com

Keywords: Vehicle, Tail gas pollution, Counter measure, Hangzhou.

\begin{abstract}
The changing trend of vehicle tail gas pollution in Hangzhou is analyzed by investigating the impacts on air quality from tail gas emission. The counter measure of building the inspection and maintain system is pointed out as well as improving management and environmental protection propaganda.
\end{abstract}

\section{Introduction}

Hangzhou is located in the southeast coast of China, is famous for its beautiful scenery, and as the capital city and transportation of Zhejiang Province, the resident population exceeded 9 million. In recent years, the number of vehicles have increased rapidly and the traffic pollution has been paid more and more attention. The old vehicles occupy a certain proportion in the use of motor vehicles; inspection and maintenance system is not perfect; road facilities are not complete; Motor vehicle exhaust emissions exceeded. After the implementation of strict industrial pollution control, the city's "ban coal" and other environmental protection measures, traffic emissions pollution gradually rise as the leading source of urban air pollution. The type of air pollution in Hangzhou is changing from coal-burning to transportation pollution.

\section{Motor Vehicle Pollution in Hangzhou}

\section{Motor Vehicle Ownership in Hangzhou}

With the development of economy, people's living standard raise fast, the number of private car sharp growth, resulting in the rapid growth of vehicles in Hangzhou. Ownership of the downtown area of Hangzhou is 1,260,000 on December 20, 2015. After 2015, the motor vehicle slowed down over the previous year, has been seriously saturated (Table 1 ).

Table 1 The annual variation of motor vehicle ownership in Hangzhou

\begin{tabular}{|l|r|r|r|r|r|}
\hline & 2011 & 2012 & 2013 & 2014 & 2015 \\
\hline Total number of motor vehicles $\left(\times 10^{4}\right.$ car $)$ & 70 & 95 & 110 & 124 & 126 \\
\hline Growth rate $(\%)$ & - & 35.7 & 15.8 & 12.7 & 1.6 \\
\hline
\end{tabular}

\section{Current Situation of Road Traffic in Hangzhou}

The total length of Hangzhou main city road (such as main road, sub road, general road) is $1700 \mathrm{~km}$, road area is $21,000,000 \mathrm{~m}^{2}$, road line density $5.5 \mathrm{~km} / \mathrm{km}^{2}$, road area density is $101200 \mathrm{~m}^{2} \cdot \mathrm{km}^{-2}$, per capita road $8.24 \mathrm{~m}^{2}$. The past six years, an increase of $2 \%$ in the road, however, the motor vehicle growth rate is about 10 times the road. 


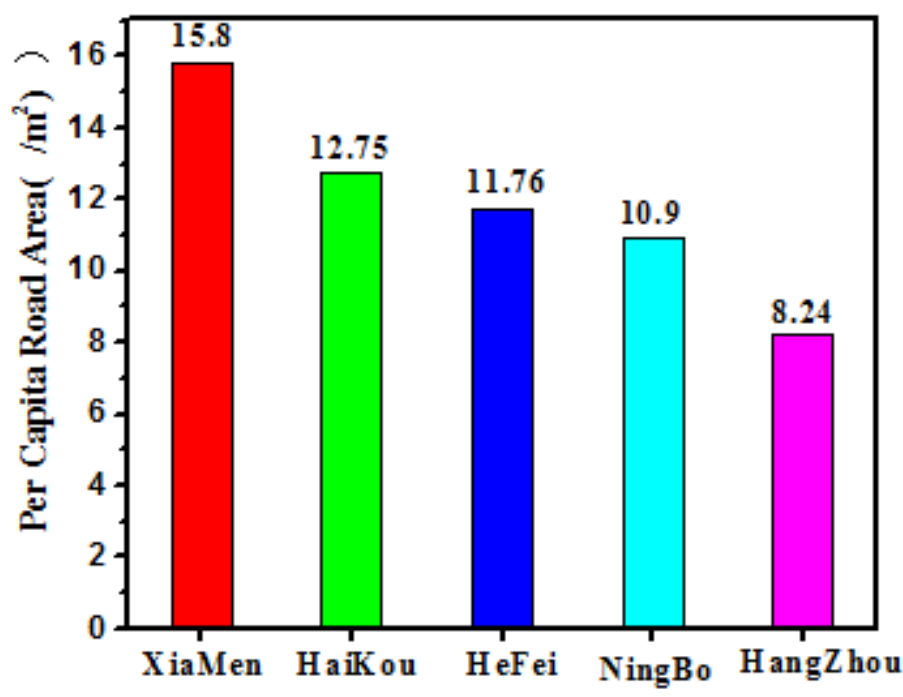

Figure 1. Per capita Road area

\section{Motor Vehicle Operation in Hangzhou}

In recent years, with the increase of the number of motor vehicles in Hangzhou, the urban road traffic is increasing rapidly. The urban transportation infrastructure and traffic management is relatively backward, resulting in the deterioration of motor vehicle use. The main urban area is a single center high-density cake layout, urban traffic flow is highly concentrated in the main urban areas. However, superimposed on the central stack in space, urban road load continued to increase. The average traffic reached 2085 car'h-1. Within the two ring road of Hangzhou becomes the highest concentration traffic and the most prominent areas of traffic conflicts. The main sections of the road traffic congestion is very serious in the morning and evening peak time. Road junctions and roads are blocked up to 31 , which significantly increased the frequency and duration of congestion. During the peak period, the average speed of the main road is about $20 \mathrm{~km} \cdot \mathrm{h}-1$. In especial, peripheral intersection of Wushan Square, Yan'an Road junction, Jiefang Road junction, Wulin gate junctions, and so on, forming a large-scale low-speed traffic dense area. Because of lack of urban road area, incomplete facilities, road traffic safety awareness, and pedestrians, non motor vehicles, motor vehicles mixed conditions have occurred, whcih making the vehicle operating conditions deteriorate further.

\section{Characteristics of Vehicle Emission Pollution in Hangzhou}

Affected by the level of social and economic development and natural conditions, old vehicles occupy a large proportion in Hangzhou, the gasoline car in the carburetor vehicle there is still a certain proportion, single vehicle emission level is high. There is still a certain proportion of carburetor vehicles in gasoline vehicles. The high emission vehicle emissions accounted for $20 \%$ of the total emissions of $60 \%$. The deterioration of motor vehicle emissions in Hangzhou, especially the serious black smoke of diesel vehicles. The new vehicle emission control is a relatively low level of the vehicle. After restrictions on motorcycles, truck city and other traffic management measures, within two loop vehicle emission pollution leading models are light-duty gasoline vehicles. Buses, taxis, and other operating vehicles have a high frequency of use, a longer driving range, a relatively serious emissions. This is 10-20\% of total pollution. Traffic flow tends to saturation in the main road, and the frequency and duration of traffic jams increased significantly. Vehicle running speed is reduced. Deterioration of operating conditions will inevitably lead to further deterioration of motor vehicle emissions. In order to obtain better dynamic performance, many drivers often make the vehicle operating under the condition of rich combustion, resulting in a further increase in hydrocarbon and $\mathrm{CO}$ emissions. 


\section{Motor Vehicle Emissions in Hangzhou}

\section{Motor Vehicle Exhaust Emissions}

Since October 2008, the environmental protection department of Hangzhou carry out sampling of motor vehicle exhaust. The statistical results show that less than $65 \%$ of national standards. The survey of 15 motor vehicle safety inspection stations in Hangzhou showed that the vehicle detection rate was between $80-88 \%$, and the first pass rate of exhaust emission was between $60-70 \%$.

Table 2. The traffic pollution estimation in Hangzhou.

\begin{tabular}{|c|c|c|c|c|c|c|}
\hline & \multirow{2}{*}{$\begin{array}{l}\text { Road } \\
\text { traffic } \\
\text { length } \\
(\mathrm{km})\end{array}$} & \multirow{2}{*}{$\begin{array}{l}\text { Section } \\
\text { number }\end{array}$} & \multicolumn{2}{|c|}{ particulate matter } & \multicolumn{2}{|c|}{ Nitrogen oxides } \\
\hline & & & $\begin{array}{l}\text { Emission } \\
\mathrm{s}\left(\mathrm{t} \cdot \mathrm{a}^{-1},\right)\end{array}$ & $\begin{array}{l}\text { Percentag } \\
\text { e }(\%)\end{array}$ & $\begin{array}{l}\text { Emissions } \\
\left(\mathrm{t} \cdot \mathrm{a}^{-1},\right)\end{array}$ & Percentage $(\%)$ \\
\hline $\begin{array}{l}\text { Urban trunk } \\
\text { road }\end{array}$ & 314.1 & 228 & 725 & 14.7 & 3574 & 18.4 \\
\hline $\begin{array}{l}\text { Urban arterial } \\
\text { road }\end{array}$ & 566.86 & 701 & 1281 & 25.9 & 5976 & 30.8 \\
\hline $\begin{array}{l}\text { City and } \\
\text { suburban roads }\end{array}$ & 628.62 & 443 & 2932 & 59.4 & 9832 & 50.8 \\
\hline Total & 1510 & 1372 & 4938 & 100 & 19382 & 100 \\
\hline
\end{tabular}

Table 3. Statistical analysis of pollution status of point, line and surface pollution source

\begin{tabular}{|l|l|l|l|l|l|l|}
\hline & \multicolumn{2}{|l|}{ Smoke (Dust) } & \multicolumn{2}{l|}{$\mathrm{SO}_{2}$} & \multicolumn{2}{l|}{ Nitrogen oxides } \\
\cline { 2 - 7 } & $\begin{array}{l}\text { Emissions } \\
\left(\mathrm{t} \cdot \mathrm{a}^{-1},\right)\end{array}$ & $\begin{array}{l}\text { Percentage } \\
(\%)\end{array}$ & $\begin{array}{l}\text { Emission } \\
\mathrm{s}\left(\mathrm{t} \cdot \mathrm{a}^{-1},\right)\end{array}$ & $\begin{array}{l}\text { Percentage } \\
(\%)\end{array}$ & $\begin{array}{l}\text { Emissions } \\
\left(\mathrm{t} \cdot \mathrm{a}^{-1},\right)\end{array}$ & $\begin{array}{l}\text { Percentag } \\
\mathrm{e}(\%)\end{array}$ \\
\hline $\begin{array}{l}\text { Traffic Line } \\
\text { Source }\end{array}$ & 5998 & 39.9 & 375 & 1.3 & 18128 & 42.3 \\
\hline $\begin{array}{l}\text { Industrial area } \\
\text { source }\end{array}$ & 3738 & 24.9 & 21945 & 77.6 & 21409 & 49.9 \\
\hline $\begin{array}{l}\text { Industrial } \\
\text { point source }\end{array}$ & 3496 & 23.3 & 4883 & 17.3 & 2351 & 5.5 \\
\hline $\begin{array}{l}\text { Life area } \\
\text { source }\end{array}$ & 1792 & 11.9 & 1061 & 3.8 & 1008 & 2.3 \\
\hline Total & 15024 & 100 & 28264 & 100 & 42896 & 100 \\
\hline
\end{tabular}

\section{The Pollution Ratio analysis of Motor Vehicle}

Due to the rapid growth of motor vehicle insurance in Hangzhou, the urban area of motor vehicle traffic is growing rapidly, and the vehicle emission pollution is becoming more and more serious. There is the 36 traffic survey of main road, secondary roads and suburbs as the foundation in Hangzhou, which evaluated by emission coefficient. In 2014, traffic pollutant emissions of particulate matter is $4938 \mathrm{t} \cdot \mathrm{a}-1$, and nitrogen oxides 19,382 t/a (Table 2). The emission of dust and nitrogen oxides from the source of the traffic lines accounted for $39.9 \%$ and $42.3 \%$ of the total pollutant emissions, respectively, as shown in Table 3. 


\section{Correlation between Vehicle Emission Pollution and Urban Air Quality}

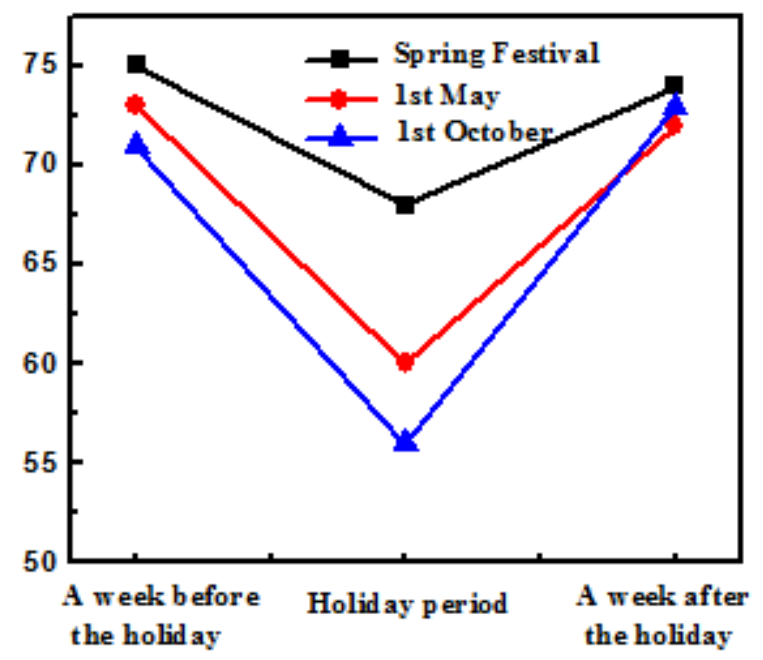

Figure 2. Changes of air quality in Hangzhou during holidays

Because of years of supervision of the industrial boiler by government and the ban on coal measures, reduce the number of industrial boilers, and NOx emissions from industrial boilers (NOx) emissions at so higher, easy to dilute diffusion. However, the nitrogen oxide (NOx) produced by motor vehicles is not conducive to spread easily. So it is easy into the breathing zone of high yield population accumulation, cause a harm to human body. In addition, the increase in the number of motor vehicles, resulting the urban air pollution contribution rate rise by motor vehicle exhaust pollution.

We analysis the data of the Spring Festival, The 1st May day, The 1st October holiday before and after 3 weeks in 2015 (Figure 2). The results show that during the holiday season, the air pollution index than the day before and after are all decline. The week average comprehensive pollution index fell in the range of 1-10 during the 3 holiday, and the air quality of the environment has improved. In addition to the weather, the main reason is the vehicle emissions during the holiday season decreased, thus the vehicle emission has an important influence on air quality changes.

Motor vehicles discharge a large number of hydrocarbons, carbon monoxide (CO), particulate matter, sulfide and other pollutants during operation. At the same time, under the ultraviolet radiation, hydrocarbon change to the secondary pollutant (such as: ozone $\left(\mathrm{O}_{3}\right)$ ). A case study of Dongfeng Road monitoring point in Hangzhou, for example, from June 31 to July 9th to monitor ozone (O3) in 2015, the data appeared excessive phenomenon during 12:00-15: 00. At this time is the largest sun direct angle radiation, it is the time of the strongest effect of ultraviolet light and the peak period of traffic flow. Analysis results show the pollution of motor vehicle is becoming the main source of air pollution in Hangzhou. There is a high correlation between urban air pollution and vehicle exhaust pollution

\section{Motor Vehicle Emission Pollution Trend}

According to the national standards for motor vehicle emission pollution levels (see Table 4), in 2009 the motor vehicle pollution index was 6 , which is close to the level of heavy pollution level of motor vehicles.

With the rapid economic development, people's income continues to increase, the number of motor vehicles will continue to grow rapidly in Hangzhou, which cause to vehicle emissions will further exacerbate pollution. Affected by the geographical environment and climate, Hangzhou is relatively easy to flow diffusion. But in the narrow environment, motor vehicle emissions in urban areas is relatively concentrated, and the discharge port is relatively low, coupled with the city of tall buildings dense, the spread of pollutants is not easy. If you encounter a suitable climate, there is a serious risk of motor vehicle pollution in some parts of the city. 
Table 4. Motor vehicle emission pollution degree calculation table

\begin{tabular}{|l|l|c|}
\hline Reference index & Partition limit & Conversion Grade \\
\hline \multirow{2}{*}{$\begin{array}{l}\text { GDP per capita } \\
\text { yuan / person) }\end{array}$} & $\mathrm{P} \geq 34000$ & 3 \\
\cline { 2 - 3 } & $34000>\mathrm{P} \geq 10000$ & 2 \\
\cline { 2 - 3 } & $10000>\mathrm{P}$ & 2 \\
\hline \multirow{2}{*}{$\begin{array}{l}\text { Motor vehicle ownership } \\
\left(\times 10^{4}\right)\end{array}$} & $200>\mathrm{V} \geq 100$ & 1 \\
\cline { 2 - 3 } \multirow{2}{*}{$\begin{array}{l}\text { Average concentration } \\
\text { of air quality }\end{array}$} & $100>\mathrm{V}$ & 3 \\
\hline \multirow{2}{*}{ Remarks } & $\mathrm{A}_{1} \geq 0.08$ & 2 \\
\cline { 2 - 3 } & $0.08>\mathrm{A}_{1} \geq 0.04$ & 1 \\
\cline { 2 - 3 } & $0.04>\mathrm{A}_{1}$ & $\begin{array}{l}\text { pollution index: } \mathrm{S}=2+2+2=6 ; \mathrm{S} \geq 7 \text { Cities with } \\
\text { heavy pollution of motor vehicles }\end{array}$ \\
\hline
\end{tabular}

\section{Main Problems}

(1) Annual inspection data does not fully reflect the situation of motor vehicle pollution, and the road inspection is not sufficient, so there was no organic connection between the annual inspection and the road inspection. For passing the test, the majority of the owners temporary maintenance before the test, leading to motor vehicle safety testing station for motor vehicle exhaust emission detection data can not effectively reflect the actual operation of the vehicle emissions. So the road inspection as an auxiliary means to play a supervisory role in motor vehicle maintenance. However, road inspection is not very well carried out because inspection personnel and equipment. There is only to the number of vehicles is relatively concentrated units such as bus companies, taxi companies and government departments to carry out sampling, so the sampling number is limited, which is not really play a supervisory role. Road inspection and annual inspection did not establish an organic complementary relationship.

(2) Lack of technical support and supervision for motor vehicle maintenance enterprises. At present, the market of motor vehicle maintenance is not uneven. Most enterprises do not have a good technical means for vehicle exhaust emissions. The administrative departments have no good technical standards and guidance for the management of motor vehicles. These are unable to effectively control the vehicle exhaust pollution.

\section{Control Measures}

\section{Establishment of Vehicle Inspection / Maintenance (I/M) System}

Motor vehicle inspection / maintenance (I/M) system is the most effective and economical method for vehicle emission pollution control at home and abroad. In the driving process, motor vehicle parts will inevitably wear and plug. These wear and tear not only affect the performance of motor vehicle fuel economy, but also affect the emission performance of motor vehicles. Motor vehicle I/M system is the role of the car in the regular and irregular detection, timely identification of high emission vehicles, found emissions exceed the standard, to take measures for the maintenance of vehicles, and strive to reach the factory so as to ensure the performance of the vehicle, the vehicle emission remained at normal level.

\section{Strengthen Supervision and Management}

Focus on annual inspection, maintenance dispersion, road inspection and supervision, re-check strict, which establish a motor vehicle exhaust testing management system maintenance, inspection and supervision in Hangzhou.

\section{Increase Environmental Awareness}

The owners and drivers are carried out relevant knowledge, enhanced environmental awareness, and consciously protect the city's atmospheric environment. 


\section{Summary}

At present, Hangzhou air quality is generally good, but with the amount of vehicle to accelerate growth, pressure will become the motor vehicle emission pollution on air quality is very larger. These are not adapt to the improvement of the quality of life of the residents and the goal of urban sustainable. The pollution caused by motor vehicle exhaust pollution is harmful to people's physical and mental health, and the destruction of urban air quality has become an important environmental factor that restricts the development of social economy and the improvement of city grade. How to deal with the contradiction between the growth of motor vehicles caused by environmental problems and the society, the government and the masses gradually high demand for environmental quality, air pollution control and reduce the resulting, continuously improve air quality of city environment, has become a very urgent task.

\section{Acknowledgements}

Youth Project of Zhejiang Natural Science Foundation of China (LQ17E080001).

\section{References}

[1] J. Hartley, E. Sørensen, and J. Torfing, "Collaborative Innovation: A Viable Alternative to Market Competition and Organizational Entrepreneurship", Public Admin. Rev., 73( 2013): 821-830.

[2] T. Meynhardt, F. E. Diefenbach,"What Drives Entrepreneurial Orientation in the Public Sector? Evidence from Germany's Federal Labor Agency”, J. Public Admin. Res. Theor 2012, 22(4): 761-792..

[3] F. Perretti, and G. Negro,"Mixing Genres and Matching People: A Study in Innovation And Team Composition In Hollywood", J. Organ. Behav. 28(2007): 563-586.

[4] J. D. Marvel, "Unconscious Bias in Citizens' Evaluations of Public Sector Performance", J. Public Admin. Res. Theor. 2016, 26(1): 143-158

[5] D. Moynihan, P. Herd, H. Harvey, "Administrative Burden: Learning, Psychological, and Compliance Costs in Citizen-State Interactions", J. Public Admin. Res. Theor. 25(2014): 43-69.

[6] M. J. Pedersen, "Activating the Forces of Public Service Motivation: Evidence from a Low-Intensity Randomized Survey Experiment", Public Administration Review ,75(2015)734-746.

[7] J. Smith, "The Motivational Effects of Mission Matching: A Lab-Experimental Test of a Moderated Mediation Model”, Public Admin. Rev. 76(2016): 626-637.

[8] W. Vandenabeele, "Development of a Public Service Motivation Measurement Scale: Corroborating and Extending Perry's Measurement Instrument",Int. Public Man. J., 11( 2008)143-167.

[9] C. N. Avellaneda, "Mayoral Decision-Making: Issue Salience, Decision Context, and Choice Constraint? An Experimental Study with 120 Latin American Mayors", J. Public Admin. Res. Theor. , 23(2013)631-661.

[10] K. Zhang, S. Batterman, Near-road air pollutant concentrations of CO and PM2.5: a comparison of MOBILE6.2/CALINE4 and generalized additive models. Atmos Environ , 44(2010)1740-1748.

[11]K. Zhang, S. Batterman, F. Dion, Vehicle emissions in congestion: comparison of work zone, rush hour and free-flow conditions, Atmos Environ , 45(2011)1929-1939. 